\section{Samoylenko I. Gnatenko M.}

\title{
RESEARCH ON ENERGY EFFICIENCY FACTORS: INSTRUMENTAL CONTROL AND VERIFICATION
}

Розглянуто переваги підходів до енергозбереження на основі застосування енергосервісного контракту (ЕСК). Проведено аналіз особливостей оцінювання ефективності енергоощадних заходів у межах ЕСК. Доведено, що основним критерієм можливості реалізації енергосервісного контракту є наявність змоги визначити та виміряти потенційну економію. Виокремлено основні проблеми щодо наявності інструментального контролю із вимірювання та верифікації енергетичної ефективності та механізми їх активізації.

Ключові слова: енергосервісна діяльність, енергоощадні заходи, ефективність енергоощадних заходів, вимірювання енергетичної ефективності.

\section{Introduction}

Today we can confidently say that the market for energy services is formed: it has active participants and energy service projects implemented in various sectors, although energy services provision has not acquired a significant spread yet. At the same time energy tariffs increasing, low energy efficiency of housing and public sectors, and financial stability reducing indicate the need to move towards the energy-efficient development options in the near future. Otherwise, economic growth will be restrained by high costs and decreasing availability of energy resources. In light of the above, the increase of economy energy efficiency by strengthening the requirements for compliance with European standards in terms of energy efficiency and implementation of Ukraine's European integration aspiration is of particular relevance and timeliness today.

\section{The object of research and its technological audit}

A scientific study on the state of instrumental control and verification of the country energy saving and energy efficiency improvement has been conducted in order to determine the priorities of sustainable energy development. There are several active programs in Ukraine now: State target economic program for energy efficiency and development of energy production from renewable sources and alternative fuels for 2010-2015 [1]; 26 regional programs for energy efficiency improvement for 2010-2014; 15 industrial programs for energy efficiency improvement for 2010-2014; 45 programs to reduce energy consumption of the budget institutions for 2010-2014.

The main document is - «National action plan for energy efficiency until 2020» [2]. It was developed according to Ukraine's commitments under the Protocol [3] of joining the Treaty establishing the Energy Community. Under this Plan Ukraine should reach until 2020 energy savings of $9 \%$ relative to the average power consumption over five years from 2005 till 2009.

However, despite the significant number of programs, projects and guidelines in the field of sustainable energy development and energy efficiency activities on methodological, informational and regulatory framework improvements are still going on.

\section{The aim and objectives of research}

The aim of the research is to analyze the state of instrumental control and verification in the spheres of energy saving and energy efficiency improvement, as well as to define the basic principles and objectives of energy efficiency measurement and verification.

The following scientific research tasks are defined to achieve this goal:

1. To explore energy saving approaches through energy service contract.

2. To conduct a comprehensive analysis on the use of evaluation indicators of energy efficiency measures.

3. To identify the factors affecting the result of energy saving activities.

4. To consider proposals to develop a methodological base for instrumental control and verification of energy saving measures within the energy service contract.

\section{Research of existing solutions of the problem}

Problems of energy efficient economy creation gained wide coverage in both foreign and domestic scientific literature. According to the European experience, the systematic organization of energy efficiency and rational energy consumption at all levels of government (country, region, city, town, village, company, person) can only provide some results. Both foreign and domestic practitioners and researchers defend this opinion in their works [4-11].

In particular, the works of $[4,6]$ focus on applying energy services to implement energy saving programs in the context of public-private partnerships. In the study [7] it is determined that ESCO are able to offer a range of services, including administrative services, at all stages of the energy efficiency project - from energy efficiency analysis and project drafting to monitoring and equipment repairing. The problem of fair providing affordable, reliable, 
efficient, environmentally sound, properly regulated and socially acceptable energy services is considered in the works of [8]. The impact of energy consumption on city energy security is also highlighted in an energy review of International Energy Agency [9].

Legislative aspects of power relations are evaluated in the works of [10], according to whom the energy relations should be regulated «towards intensification of international cooperation and concluding appropriate bilateral and multilateral agreements that should focus on implementation of the Ukrainian Energy Strategy and the national interests». The specific use of the mechanism of energy saving measures financing through ESCOs with the return of borrowed funds from the city budget is carefully examined in the work of [11].

The results of researches give us the unanimous conclusion - solving the problem of energy saving and energy efficiency has a long-term nature, due to the need to, firstly, change the system of relations in the energy markets, and secondly - to replace and modernize a large part of the production, engineering and social infrastructure, development of which should be based on innovation. Despite the significant research achievements in the field of energy saving by energy service implementation, the problem of introducing methodological base for instrumental control and verification of energy saving measures still remains poorly explored nowadays.

\section{Methods of research}

The systematic approach (in the disclosure of the subjects, principles and tools for energy service activities), methods of analysis and synthesis, logic synthesis, analogies and comparative mapping were being used while achieving the goals of the study.

\section{Research results}

Analysis of possible ways of energy efficiency improvement indicates that implementation of most energy saving and energy efficiency measures is attractive for private investment. In fact, the private sector activity indicates the successfulness of state policy in the field of energy saving and energy efficiency.

One of the instruments to appeal private investment is the energy services market; its development will help to solve the perennial problem of lack of sufficient investment resources for the modernization of energy sector, municipal infrastructure and public sector. In addition, a wide scope of work can be performed within the energy service, including reconstruction of buildings, major repair, equipment installation etc. Hence, it becomes clear why overseas practice implementing energy saving projects through the establishment of specialized energy service companies (ESCOs) operating on the basis of energy service contract (ESC) has become widespread. Table 1 clearly demonstrates the benefits of energy saving approach based on ESC.

The main requirement to content and structure of an ESC is the existence of a list of measures aimed at power saving and energy efficiency improvement. Observance of the requirements is mandatory for the ESC Contractor. However, you need to pay attention to the following points: - The maximal effectiveness of an energy saving measure (ESM) involves a comparison of a number of alternative technical solutions in terms of feasibility;
- The decision to include certain measures to ESC is made on the basis of their energy performance and cost-effectiveness;

- The effectiveness of any ESM should be assessed taking into account the interests of all parties - participants of energy service: Initiator - Customer Contractor - Investor - Consumer.

Table 1

The benefits of ESC-based energy saving approaches

\begin{tabular}{|c|c|}
\hline Traditional approach & E5Г \\
\hline \multicolumn{2}{|c|}{ Energy audit } \\
\hline $\begin{array}{l}\text { A «classic energy audit» without } \\
\text { the development of mechanisms of } \\
\text { financing and energy saving mea- } \\
\text { sures implementation, monitoring } \\
\text { and verification of results. All the } \\
\text { risks of achieving the stated results } \\
\text { are placed on the customer }\end{array}$ & $\begin{array}{l}\text { A so-called «investment energy audit», } \\
\text { which involves determining the energy } \\
\text { consumption baselines, financing and } \\
\text { implementation mechanisms as well } \\
\text { as monitoring and verification of re- } \\
\text { sults. Most of the risks of achieving } \\
\text { the stated results are placed on ESCO }\end{array}$ \\
\hline \multicolumn{2}{|c|}{ Projects financing } \\
\hline $\begin{array}{l}\text { Enterprises use mostly their own } \\
\text { funds, resulting in implementation of } \\
\text { mainly low-cost and quick BOI ener- } \\
\text { gy saving measures with little effect }\end{array}$ & $\begin{array}{l}\text { Allows to eliminate the major part of } \\
\text { enterprises own funds use, enabling } \\
\text { realization of highly efficient long-term } \\
\text { investment projects }\end{array}$ \\
\hline \multicolumn{2}{|c|}{ Projects implementation } \\
\hline $\begin{array}{l}\text { Energy efficiency measures imple- } \\
\text { mentation is usually placed on the } \\
\text { chief energy officer's department as } \\
\text { minor and non-core task }\end{array}$ & Implemented by ESCs \\
\hline
\end{tabular}

Considering that one of the purposes of ESM effectiveness evaluation within the ESC is justification for option selection by comparing the cost of the measure and its energy saving effect (for production, transportation or consumption), we should specify sequence and conditions of ESM assessment indicators using.

The total sequence of information processing and interpreting of the calculation results is as follows:

- Evaluation of the measure implementation effect in physical terms is based on algorithms specified while implementing typical projects for power saving and energy efficiency;

- Evaluation of the actual effect of measure implementation in physical terms is based on comparison of actual energy and water consumption for the base and study periods;

- Comparable conditions, which composition depends on the type of energy resource and technical nature of the measures, are taken into account when calculating the effect of the measure implementation;

- When assessing the effect of the ESM implementation the factors of their mutual influence are taken into consideration;

- Annual energy savings in terms of value are calculated on the basis of data from contracts with energy supplying organizations;

- The estimated cost of the measures implementation is calculated according to the typical projects data;

- The investment efficiency;

- The payback period of the measures implemented is calculated and compared to the actual payback period; - The conclusion on the effectiveness of each measure implemented is based on the criteria for evaluation of all measures implementation effectiveness. 
For events that at the time of accounting documentation formation did not affect the energy consumption from outside causes that directly or indirectly did not impacted the performance of complex technical and organizational measures, indicators in physical and value terms are calculated theoretically. This refers to the fact that the lack of statistical information about the impact of measures to changes in energy and water consumption excludes the possibility of calculation of the measure introduced actual effect. So the calculation is carried out at a theoretical level only. For example, an event aimed at changing the thermal energy consumption is introduced in the unheated period and the date of reporting documents filing is set up within the unheated period. In this case, there is no physical possibility to calculate the actual effect of the event neither in physical nor in value terms. In this case these performance indicators are calculated theoretically. The overall list of ESM implementation performance indicators is shown in Table 2.

Table 2

Criteria for evaluation the effectiveness of the measures implementation

\begin{tabular}{|c|l|}
\hline $\begin{array}{c}\text { Index } \\
\text { number }\end{array}$ & \multicolumn{1}{|c|}{ Name of criterion } \\
\hline 1 & Net profit \\
\hline 2 & The simple payback period of investments \\
\hline 3 & ROI \\
\hline 4 & The maximum possible term of full repayment \\
\hline 5 & Net present value \\
\hline 6 & BOI index \\
\hline 7 & Internal rate of return \\
\hline 8 & Discounted payback period \\
\hline 9 & The total discounted costs \\
\hline 10 & Specific discounted costs \\
\hline 11 & Internal rate of return adjusted for inflation \\
\hline 12 & Net present value inflation \\
\hline 13 & Net present value adjusted for risk of capital investment \\
\hline 14 & The annual energy savings for the measure in physical terms \\
\hline 15 & The annual energy savings for the measure in terms of value \\
\hline
\end{tabular}

The given above criteria are not, however, able to fully estimate the effect of energy saving measures implementation. Full and objective evaluation of ESM realization results enables the calculation of targets in the field of power saving and energy efficiency improvement. It should be noted that targets reflect the savings of certain energy types: electricity, heat, water and natural gas savings in physical and value terms. In addition, a complex assessment is not possible beyond the measurement and verification (savings). It is meant that during the ESM implementation we should correctly calculate the actual value of savings because of the comparability of conditions. These are comparable conditions - factors influencing consumption of energy resources (weather changes, changes in operating mode, changes in purpose of premises, space etc.) that require appropriate measurements [12].

Measurement and verification of energy efficiency is the process of using measurements to determine the actual value of the savings (taking into account comparable conditions), obtained at a particular site as a result of the implementation of energy efficiency improvement measures [12]. Measurement and verification of energy efficiency cover the following operations:

1) Installation, verification and maintenance of meters;

2) Collection and verification of data;

3) Development of calculation methods and acceptable estimates;

4) Calculations on the basis of the measurements data;

5) Reporting, quality assurance and reports verification by a third party.

Procedures for measurement and verification in energy service contracts are crucial because they can ensure that all planned energy saving measures are calculated correctly, hence, will make it possible to achieve the results planned. Procedures for measurement and verification have to, firstly, accurately reflect current changes at the energy service facility that affect energy efficiency, and secondly, operate on a transparent basis of savings calculation, because the investor must be sure of the result. Table 3 presents goals of energy efficiency verification measurements.

The mechanism of saving determining, its criteria and the list of engaged mathematical models - all this should be reflected in savings instrumental control (measurement) and confirmation (verification) plan, which, for its part, is an essential element of any energy service contract.

According to the source [13] this plan should include:

1) A description of energy saving measures;

2) The expected results of their implementation and procedures for acceptance of these results, which directly confirm the success of a particular energy saving measure;

3) The determination of the measurement boundaries and the places for metering devices installation;

4) Criteria of comparable conditions and expected changes.

Today, the national practice of savings measurement and verification has no appropriate instruments and necessary methodological support. The absence of clear and public procedures significantly impedes the implementation of energy services model.

In the US and several European countries the problem of measurement and verification of energy savings has long been the subject of scientific and public debates. There are at least three guides of successfully proven methods and techniques of measurement and verification of achieved energy savings in world practice:

- International performance measurement and verification protocol IPMVP [12] exists in different versions since 1995. This protocol was developed by the Coalition of international organizations (led by the US Department of Energy) in 1994-1995. The protocol has actually become the national standard of measurement and verification of the achieved energy savings in the US and many other countries, including European, and has been translated into more than ten languages. - Measurement and Verification Guides of the Federal Energy Management Program [14], that contains procedures and management principles used in the quantitative assessment of the savings obtained by the improved operation and maintenance of equipment and systems, increased equipment energy efficiency and other projects, and implemented in the field of energy saving within the state level performance contracts. The document is intended for heads of executive branch 
agencies, government customers and contractors that implement projects in US federal institutions.

- ASHRAE Guideline for Measurement of Energy and Demand Savings (American Society of Heating, Refrigerating and Air-Conditioning Engineers) [15], developed by the members of the Committee of the American Society of Engineers of heating, cooling and air conditioning. The purpose of the ASHRAE guideline - is to provide a specified level of effectiveness in measuring of energy savings and demand as a result of implementation of projects in energy saving and energy efficiency improvement. The document applies to residential, commercial and industrial buildings.

Table 3

The goals of energy efficiency measurement and verification

\begin{tabular}{|c|c|}
\hline The problem solved & \\
\hline $\begin{array}{l}\text { Increase energy resour- } \\
\text { ces savings }\end{array}$ & $\begin{array}{l}\text { An accurate determination of the energy sa- } \\
\text { vings provides organizations leaders feedback } \\
\text { on the effect of the implemented energy saving } \\
\text { measures. This feedback helps them adjust their } \\
\text { own plans or energy saving measures, allows to } \\
\text { get a greater effect and reduces the degree of } \\
\text { deviation from goals }\end{array}$ \\
\hline $\begin{array}{l}\text { The financial transactions } \\
\text { documentation }\end{array}$ & $\begin{array}{l}\text { For energy service contracts the amount of energy } \\
\text { saving is the basis for the determination of the next } \\
\text { payment to the energy service company (ESCD), } \\
\text { or proof that the value of savings, which un- } \\
\text { der the contract was guaranteed by ESCD, is } \\
\text { reached. Well-formed and implemented plan of } \\
\text { energy efficiency measurement and verification } \\
\text { may become the basis for transparent and clear } \\
\text { documentation of the value of savings achieved }\end{array}$ \\
\hline $\begin{array}{l}\text { Attraction of funding for } \\
\text { efficiency improvement } \\
\text { projects }\end{array}$ & $\begin{array}{l}\text { Well-formed plan of energy efficiency measure- } \\
\text { ment and verification increases the reliability of } \\
\text { reports on the results of measures to improve } \\
\text { this efficiency. It also increases the likelihood of } \\
\text { forecasting calculations to evaluate the results } \\
\text { of energy efficiency investments. This reliability } \\
\text { instills confidence of the financial institutions in } \\
\text { energy saving and energy efficiency improvement } \\
\text { projects, increases the chances for adequate } \\
\text { funding }\end{array}$ \\
\hline $\begin{array}{l}\text { Improving the quality of } \\
\text { facility design, operation } \\
\text { and maintenance }\end{array}$ & $\begin{array}{l}\text { Development of a well-formed plan of energy } \\
\text { efficiency measurement and verification promotes } \\
\text { balance, complexity of project solutions. Sophis- } \\
\text { ticated plan of energy efficiency measurement } \\
\text { and verification also helps managers to identify } \\
\text { and solve the problems arising in the facility } \\
\text { maintenance and operation, hence the operation } \\
\text { of the facility becomes more efficient. In addition, } \\
\text { this provides design companies the necessary } \\
\text { information for similar future projects }\end{array}$ \\
\hline Energy costs planning & $\begin{array}{l}\text { Applicable to standard methods of energy effi- } \\
\text { ciency measurement and verification help mana- } \\
\text { gers to plan expenditures considering changes in } \\
\text { operating conditions }\end{array}$ \\
\hline
\end{tabular}

The need for creating and implementing the similar or fully identical national methodological framework in Ukraine is a priority condition. It is doubtless that its formation must be based on the experience of foreign countries. National methodological framework will help to create a unified approach to determining energy savings of the ESM within the ESC. Lack of regulatory and methodological documents regulating activity in this area prevents the emergence of effective mechanism for identification and justification of cost savings from ESM implementation in the context of ESC.

\section{SWOT analysis of research results}

Strengths. The strength of the research conducted is the analysis of the factors for evaluating the ESM efficiency within the ESC and the justification of the need for creating and implementing national methodological framework of measurement and verification of energy savings achieved.

Weaknesses. The weak point is that the data regarding energy service activities is not always objective, because in modern Ukraine there are many companies that position themselves as ESCOs, but their activities are usually related to the supply of meters, energy saving equipment and materials, energy surveys or energy supplement. These companies usually have no relationship with energy saving measures, energy efficiency improvement and the customer's results in real energy resources savings.

Opportunities. The opportunities for further research are the adoption of international experience on the implementation of certain ESC types and models of funding for these contracts in Ukraine; the development of methodological basis for the standardized reporting form of achieving the intended amount of energy savings; methodological basis of formal methods and documentary substantiation of projects effectiveness evaluation.

Threats. The threat to the research results is impossibility to adopt a positive experience of application of these measurement and verification guidelines in the Ukrainian situation. It is caused by primary need to adopt to local conditions the terminology normalization and legal regulation of basic principles of energy saving and energy efficiency improvement. In the way of successful implementation of such projects are significant differences in the principles of the entire energy sector of Ukraine and other countries, unstable conditions for small and medium businesses, high financial and political risks that affect the development of energy servicing in the country.

\section{Conclusions}

1. The approaches to energy saving through energy service contract are researched. It is determined - that the main requirement to the content and structure of the ESC is the existence of a list of measures aimed at energy saving and energy efficiency improvement. The energy saving measures effectiveness should be assessed taking into account the interests of all participants of energy services: Initiator - Customer - Contractor - Investor - Consumer. It is also proved that achieving of proper energy efficiency level by each party measures is the overall performance of energy servicing.

2. The use of indicators to evaluate energy saving measures is analyzed. The procedure for evaluation of the energy saving measures is given. It is noted that the obligatory prerequisite for evaluation of the results of the energy saving measures implementation, is evaluation of both in physical and value terms.

3. Factors and indicators affecting the result of energy saving measures implementation are defined. It is proved that the success of any ESC depends on the 
correct calculation of savings from energy effectiveness measures implementation. It is necessary to develop appropriate methodological framework of formal methods and documentary substantiation of the projects effectiveness evaluation in order to regulate the provision of standardized and unified norms and approaches to the determination of energy efficiency indicators (target indicators).

Target indicators have to be, firstly, potentially achievable, and secondly, evaluated on the basis of statistics, reporting and opinion poll of organization employees with mandatory appeal to information sources. They should provide a quantitative and qualitative assessment of the level of achievement of energy saving and energy efficiency improvement purposes.

4. The ways to develop a methodological framework for methods of energy efficiency measurement and verification are proposed. Procedure for measurement and verification of energy efficiency involves the inspection of facilities, energy usage measuring, independent variables monitoring, calculations, including computation of target indicators values in the field of energy saving and energy efficiency improvement in comparable conditions, as well as computation of energy consumption reduction in comparable conditions. Creation of a comprehensive methodological framework, without any doubts, will make possible energy servicing market development, increase investment in energy saving and energy efficiency improvement projects, contribute to the professional growth and realization of specialists in energy saving and energy efficiency.

\section{References}

1. Pro zatverdzhennia Derzhavnoi tsilovoi ekonomichnoi prohramy enerhoefektyvnosti i rozvytku sfery vyrobnytstva enerhonosiiv z vidnovliuvanykh dzherel enerhii ta alternatyvnykh vydiv palyva na 2010-2015 roky [Electronic resource]: Decree of the Cabinet of Ministers of Ukraine from 01.03.2010 № 243. Available at: \www/URL: http://zakon0.rada.gov.ua/laws/ show/243-2010-п

2. Pro Natsionalnyi plan dii $z$ enerhoefektyvnosti na period do 2020 roku [Electronic resource]: Decree of the Cabinet of Ministers of Ukraine from 25.11.2015 № 1228-p. - Available at: \www/URL: http://zakon0.rada.gov.ua/laws/show/1228-2015-p

3. Protokol pro pryiednannia Ukrainy do Dohovoru pro zasnuvannia Enerhetychnoho Spivtovarystva [Electronic resource]: Protocol from 24.09.2010. - Available at: \www/URL: http:// zakon3.rada.gov.ua/laws/show/994_a27

4. Sorrell, S. The economics of energy service contracts [Text] / S. Sorrell // Energy Policy. - 2007. - Vol. 35, № 1. - P. 507-521. doi:10.1016/j.enpol.2005.12.009

5. Hansen, S. J. ESCOs Around the World: Lessons Learned in 49 Countries [Text] / S. J. Hansen, P. Bertoldi, P. Langlois. Lilburn: The Fairmont Press, 2009. - 377 p.

6. Hansen, S. J. ESCOs Around the World [Text] / S. J. Hansen // Strategic Planning for Energy and the Environment. - 2011. Vol. 30, № 3. - P. 9-15. doi:10.1080/10485236.2011.10388615

7. Energy Service Companies [Electronic resource] // EU Commission. Joint Research Centre. - Available at: \www/URL: https://ec.europa.eu/jrc/en/energy-efficiency/eed-support/ energy-service-companies
8. Lilliestam, J. Conceptualising Energy Security in the European Context [Electronic resource] / J. Lilliestam, A. Patt. - Smart Energy for European Platform, 2012. - 30 p. - Available at: \www/URL: http://www.sefep.eu/activities/publications-1/ conceptualising\%20energy\%20security\%20in\%20Europe.pdf

9. World Energy Outlook 2008 [Text] / International Energy Agency. - Paris: StediMedia, 2008. - 578 p.

10. Mytsa, N. V. Vazheli derzhavnoho rehuliuvannia na rynku enerhoresursiv [Text] / N. V. Mytsa // Innovatsiina ekonomika. 2012. - № 2 (28). - P. 306-311.

11. Novoseltsev, O. V. Mekhanizm ekonomichnoho stymuliuvannia enerhozberezhennia na pidpryiemstvakh komunalnoi vlasnosti [Text] / O. V. Novoseltsev, T. O. Yevtukhova // The Problems of General Energy. - 2003. - № 8. - P. 40-47.

12. EVO 10000-1:2010. International Performance Measurement and Verification Protocol. Concepts and Options for Determining Energy and Water Savings. Volume 1 [Electronic resource]. Efficiency Valuation Organization, 2010. - Available at: \www/ URL: http://www.mcn-solutions.com/resources/International\%20Performance\%20Measurement\%20and\%20Verification\%20 Protocol\%202010.pdf

13. Efficiency Valuation Organization [Electronic resource]. - Available at: \www/URL: http://evo-world.org/en/

14. M\&V Guidelines: Measurement and Verification for Performance-Based Contracts. Version 4.0 [Electronic resource]. - U.S. Department of Energy Federal Energy Management Program, 2015. - Available at: \www/URL: https://energy.gov/sites/ prod/files/2016/01/f28/mv_guide_4_0.pdf

15. American Society of Heating, Refrigerating, and Air Conditioning Engineers (ASHRAE) [Electronic resource]. - Available at: \www/URL: http://www.ashrae.org

\section{ИССЛЕДОВАНИЕ ФАКТОРОВ ЭНЕРГЕТИЧЕСКОЙ ЗФФЕКТИВНОСТИ: ИНСТРУМЕНТАЛЬНЫЙ КОНТРОЛЬ И ВЕРИФИКАЦИЯ}

Рассмотрены преимущества подходов к энергосбережению на основе применения энергосервисного контракта (ЭСК). Проведен анализ особенностей оценки эффективности энергосберегающих мероприятий в пределах ЭСК. Доказано, что основным критерием возможности реализации энергосервисного контракта является наличие возможности определить и измерить потенциальную экономию. Выделены основные проблемы о наличии инструментального контроля с измерения и верификации энергетической эффективности и механизмы их активизации.

ключевые слова: энергосервисная деятельность, энергосберегающие мероприятия, эффективность энергосберегающих мероприятий, измерения энергетической эффективности.

Samoylenko Inna, PhD, Associate Professor, Department of Management and Administration, O. M. Beketov National University of Urban Economy in Kharkiv, Ukraine, e-mail: samoylbox@gmail.com, ORCID: http://orcid.org/0000-0002-3623-4998

Gnatenko Maryna, Senior Lecturer, Department of Management and Administration, O. M. Beketov National University of Urban Economy in Kharkiv, Ukraine, ORCID: http://orcid.org/0000-00025681-6944 